\title{
Progress and promenade
}

Architecture is shaped by movement, and the technologies of movement; in the Acropolis, Athens - as shown in the Parthenon frieze - the pace of procession is that of sandal, chariot and horse. So things continued, more or less, up to the nineteenth century until, in Rain, Steam, and Speed (1844), Turner's Great Western steam train erupts from the canvas in a new Sublime of swiftness. Marko Jobst, in his opening 'Perspective' on the London Underground (pp. 105-107), examines the destabilising impact of rail, as in the glazing wagons of the Crystal Palace, London (1851), (anticipating those pre-cast housing schemes laid out, not for human flows, but for the logistics of the crane-track); thence to the arcade-as-railway and the London Underground, the very abstraction it seems - as in Harry Beck's topological map (1931) - of networks and nodes of movement, yet at the same time (apart from the iconic 'tube-station' halls) resistant, in its enfolded mysteries, to the interpretative tools of modernism.

It all changed again with the invention of the motor-car, and the ground floor of Le Corbusier's Villa Savoye, famously drawn by the turning circle of the luxury vehicle that enabled this weekend idyll from Paris. Hans Scharoun's Schminke House, near Dresden, was also designed to be arrived at by car. Flora Samuel and Peter Blundell Jones compare the promenade architecturale in these two epochal projects (pp. 108-124); Corbusier's promenade is inscribed in the pure gestalt of the object, but in Scharoun form is discovered through the flow of the promenader - distinct attitudes to movement that between them articulate much of the Modernist legacy. Leaving the car, progression continues anciently on foot, up those Acropolis-like ramps in the case of Villa Savoye, to the calm prospect of a 'Virgilian dream' - but not so calm in truth, as it has been forever disturbed by the new capacity for speed.

Two papers investigate aspects of the Islamic world where paths and places are traditionally realised as intricate, sequentially shadowed and illuminated carpets of gateways and spaces. Magda Sibley and Iain Jackson's work on Islamic public baths (hammam, pp. 155-170) looks at their typologies and subtle configurations of arrival, transition, and bathing places, in the context of rituals of undressing, social interaction and gossip, and spiritual and physical cleansing. Özgür Ediz and Michael J. Ostwald study Sinan's great Süleymaniye Mosque in Istanbul through fractal examination of its form, ornament and materiality (pp. 171-182). These might be said to reflect levels of encounter; from the distant silhouette of the building, to those key symbolic elements and gateways where ornament accrues in intensity, down to the textures of material, and jointing of stone - the last less 
consciously designed perhaps, but inherent to the complexity of the built work and its analysis. Many architects today, awkwardly seeking a new ornament, can seem like amateurs as they rediscover lost skills of textural gradation, and that Ruskinian awareness of what ornament means when viewed at long distance or closely by. As in this essay, digital and fractal tools are already often inherent to these new, or re-found, modes of interpretation and making.

On a surface reading Dom Hans van der Laan's poetics of space - built on notions of 'cell, court and domain' - seems to respect a similar traditional order; but Caroline Voet discovers a new 'polyrhythmic space', in her interpretation of his convent at Tomelilla (pp. 137-154), that is neither classical or modern functionalist, one that is experienced as 'a continuous whole' defined as it is 'by several series and their spatial superimposition'.

Yet - somewhere between installation, art-practice, and architecture itself- Gordon Matta-Clark's slices and voidings subvert any of the above more normative expectations of boundary and threshold in building, as examined in Bahar Beşlioğlu and Ayşen Savaş's study of his 'programmatic experimentation' (pp. 171-182). 